Article

\title{
The Impacts of Recently Established Fish Populations on Zooplankton Communities in a Desert Spring, and Potential Conflicts in Setting Conservation Goals
}

\author{
Sujan M. Henkanaththegedara ${ }^{1, \dagger}{ }^{,}$Justin D. L. Fisher ${ }^{1}$, Daniel C. McEwen ${ }^{2}$ and \\ Craig A. Stockwell 1,*
}

1 Environmental and Conservation Sciences Graduate Program, Department of Biological Sciences, North Dakota State University Dept. 2715, P.O. Box 6050, Fargo, ND 58108-6050, USA; E-Mails: Henkanaththegedarasm@longwood.edu (S.H.); Justin.d.fisher@ndsu.edu (J.F.)

2 Biosciences Department, Minnesota State University Moorhead, 1104 7th Avenue South, Moorhead, MN 56563, USA; E-Mail: mcewenda@mnstate.edu

$\dagger$ Present address: Department of Biological \& Environmental Sciences, Longwood University, 201 High Street, Farmville, VA 23909, USA.

* Author to whom correspondence should be addressed; E-Mail: craig.stockwell@ndsu.edu; Tel.: +1-701-231-8449.

Academic Editor: Thilina Surasinghe

Received: 1 December 2014 / Accepted: 4 January 2015 / Published: 9 January 2015

Abstract: Desert springs, which harbor diverse and endemic invertebrate assemblages, are
often used as refuge habitats for protected fish species. Additionally, many of these springs
have been colonized by invasive fish species. However, the potential impacts of recently
established fish populations on invertebrate communities in desert springs have been
relatively unexplored. We conducted a mesocosm experiment to assess the impact of both
protected and invasive fish on community structure of spring-dwelling invertebrates
focusing on zooplankton. Experimental populations of spring zooplankton communities
were established and randomly assigned to one of three treatments, (1) invasive western
mosquitofish (Gambusia affinis); (2) endangered Mohave tui chub (Siphateles bicolor
mohavensis); and (3) fishless control. Final populations of zooplankton and fish were
sampled, sorted, identified and counted. The treatment differences of zooplankton communities
were analyzed by comparing the densities of six major zooplankton taxa. Further, we
performed nonmetric multidimensional scaling (NMDS) to visualize the patterns of 
zooplankton community assemblages. Four zooplankton taxa, crustacean nauplii, cladocera, calanoid and cyclopoid copepods had significantly lower densities in fish treatments compared to fishless control. Overall, invasive mosquitofish caused a $78.8 \%$ reduction in zooplankton density, while Mohave tui chub caused a $65.1 \%$ reduction. Both protected and invasive fish had similar effects on zooplankton except for cladocerans where tui chub caused a $60 \%$ reduction in density, whereas mosquitofish virtually eliminated cladocerans. The presence of fish also had a significant effect on zooplankton community structure due to population declines and local extirpations presumably due to fish predation. This work shows that conservation-translocations undertaken to conserve protected fish species may impact spring-dwelling invertebrate communities, and such impacts are similar to impacts due to colonization by invasive fish species.

Keywords: desert springs; spring invertebrates; spring zooplankton; protected species; endangered species; invasive species; alien species

\section{Introduction}

Desert springs function as "keystone" ecosystems playing a major role in evolutionary processes and regional biodiversity [1,2]. Furthermore, desert springs host the highest number of locally endemic taxa in North America making them one of the biodiversity hotspots and priority sites for conservation [1-3]. Recent studies have uncovered unique, highly diverse and endemic invertebrate assemblages, both macroinvertebrates and zooplankton, from North American desert springs [4-12]. These systems are of particular conservation concern because many spring invertebrates are threatened with extinction due to anthropogenic impacts, such as water mining, habitat alterations, and introduction of non-native species [1,3,13].

Many desert springs have been stocked with non-native fish species [13-16] mainly to control mosquito-borne diseases (western mosquitofish Gambusia affinis [15]), to promote sport fishing (large-mouth bass Micropterus salmoides [17]), and as breeding ponds for aquarium fish (sailfin molly Poecilia latipinna [16]). More recently, desert springs have been stocked with federally and state protected fish species as a strategy to create refuge populations as a hedge against extinction [18,19]. For example, endangered species such as the Gila topminnow Poeciliopsis occidentalis occidentalis [18], Mohave tui chub Siphateles bicolor mohavensis [20] and Pahrump poolfish Empetrichthys latos latos [21] have been transplanted to historically fishless springs as a conservation strategy.

While conservation translocations have reduced extinction probability for many protected fish species $[18,19,22]$, the effects of such translocations on native and endemic invertebrate species have been relatively unexplored. However, newly established protected fish populations may impact spring invertebrate communities (both macroinvertebrates and zooplankton) due to predation. Such deleterious impacts by newly established fish populations on rare native invertebrate communities pose potential conflicts when setting conservation goals [23-25].

Most research concerning fish impacts on invertebrate communities has focused on the effects of invasive mosquitofish (Gambusia affinis and G. holbrooki) [26-28]. Hurlbert et al. [26] showed that 
experimental mosquitofish populations (G. affinis) eliminated cladocerans and significantly reduced densities of rotifers, crustaceans and aquatic insects in experimental mesocosms. Further, Linderiella occidentalis, a fairy shrimp species endemic to California vernal pools, had lower survival in experimental ponds sympatric with western mosquitofish compared to control ponds [29]. However, very little work has been conducted on the impacts of fish introductions on aquatic invertebrate communities in desert spring systems [14,17,30].

We examined the effects of non-native western mosquitofish and protected Mohave tui chub (S. b. mohavensis) on spring zooplankton communities using a mesocosm experiment. Both of these fish species have been historically transplanted to fishless springs. Western mosquitofish have been widely introduced to desert springs [14,23,30], while Mohave tui chub populations have been translocated to in many historically fishless desert springs [20,31].

Recent conservation translocations of Mohave tui chub (family: Cyprinidae) have been pursued because of its limited range and risk of extinction. It was the only fish native to the Mojave River in California [32], and river populations were extirpated in the late 1960s mainly due to habitat modification and invasive species [32,33]. Currently there are five stable populations of this species but three of them are infested with invasive western mosquitofish [32]. It is a federally and state listed endangered species due to its restricted range and the extant populations are not considered secure due to a variety of threats including the potential impacts of mosquitofish. Thus, the Mohave tui chub recovery plan calls for more transplants to secure the species [32].

We compared the zooplankton communities of fishless control mesocosm, to mesocosms stocked with either Mohave tui chub or western mosquitofish to assess the potential impacts of recently established fish populations (both endangered and invasive) on spring zooplankton communities.

\section{Experimental Section}

\subsection{Experimental Setup}

We conducted a mesocosm experiment mimicking the spring environmental conditions of one of the principal refuge habitats for the Mohave tui chub, Lake Tuendae at the Desert Studies Center in Zzyzx, California. In addition to Mohave tui chub, Lake Tuendae hosts invasive western mosquitofish and a small introduced population of Saratoga Springs pupfish (Cyprinodon nevadensis nevadensis). It is a highly modified desert spring [33] approximately $140 \times 40 \mathrm{~m}$ in size with a maximum depth up to about two meters.

We established 25 large circular plastic mesocosms adjacent to Lake Tuendae to host experimental populations of aquatic invertebrates in the absence of fish and in the presence of Mohave tui chub and western mosquitofish (from 8 March 2009 to 12 May 2009). At the onset of experiment, mesocosms were filled with water from Lake Tuendae to introduce invertebrate communities, but filtered through $1.18 \mathrm{~mm}$ mesh to exclude larval fish, which is critical for our experimental design. This also eliminated macroinvertebrates, which represents about $2 \%$ of total invertebrate community in Lake Tuendae [34]. Each tank was provided with a constant aeration system, equal amounts of plastic "plants" to provide cover and substrate, and poultry fence to exclude avian predators. Five mesocosms were designated as fishless controls, whereas 20 mesocosms were randomly assigned to one of two fish treatments each 
with 10 replicates: Mohave tui chub (MTC) and western mosquitofish (WMF). All 20 mesocosms with fish and two fishless mesocosms had a diameter of $1.8 \mathrm{~m}$ (volume $\sim 1200 \mathrm{~L}$ ), whereas three additional fishless mesocosms had a diameter of $2.5 \mathrm{~m}$ (volume $\sim 2600 \mathrm{~L}$ ). However, we maintained the water levels of all the tanks at about $45 \mathrm{~cm}$. The final zooplankton densities were not significantly different between the large fishless and small fishless mesocosms indicating lack of tank size effects on zooplankton densities (Table 1).

Table 1. The final zooplankton densities in small (volume $\sim 1200 \mathrm{~L}$ ) and large (volume $\sim 2600 \mathrm{~L}$ ) tanks used for fishless control treatment. The averages were tested with Wilcoxon rank sum test for any significant differences.

\begin{tabular}{lcccc}
\hline \multicolumn{1}{c}{ Invertebrate } & \multicolumn{2}{c}{ Average Density $($ per $\mathbf{L} \pm$ SE) } & W & $\boldsymbol{p}$-Value \\
\hline \multicolumn{1}{c}{ Group } & Small Tank $(\boldsymbol{n}=\mathbf{2})$ & Large Tank $(\boldsymbol{n}=\mathbf{3})$ & & \\
\hline Rotifers & $19,841.0( \pm 10,459.0)$ & $31,516.7( \pm 2534.5)$ & 1 & 0.4 \\
Crustacean nauplii & $39.8( \pm 1.3)$ & $33.2( \pm 31.9)$ & 6 & 0.2 \\
Cladocera & $277.0( \pm 29.0)$ & $264.0( \pm 21.2)$ & 4 & 0.8 \\
Calanoid copepods & $20.5( \pm 9.0)$ & $25.2( \pm 7.1)$ & 2 & 0.8 \\
Cyclopoid copepods & $105.0( \pm 51.0)$ & $67.2( \pm 28.2)$ & 5 & 0.4 \\
Water mites & $12.0( \pm 2.0)$ & $4.5( \pm 1.5)$ & 6 & 0.2 \\
\hline
\end{tabular}

Tanks were stocked with adult Mohave tui chubs and mosquitofish captured from Lake Tuendae using minnow traps and hand nets. Mesocosms receiving Mohave tui chubs (MTC) were each stocked with eight adult Mohave tui chubs (Total length $=80-120 \mathrm{~mm}$ ). Mesocosms receiving mosquitofish (WMF) were each stocked with 25 male and 50 female mosquitofish and they were not measured due to initial mortality associated with handling stress. These fish densities were chosen to reflect relative densities and sex ratios in Lake Tuendae [34]. The final fish population size upon completion of this experiment was reported elsewhere [35]. We did not include Saratoga Springs pupfish, because this species was at very low density when our experiments were conducted. Fish were fed ground pelleted fish food at a ration of $4 \%$ of stocked fish biomass per day complying with animal care protocols (NDSU IACUC \#A0902).

\subsection{Zooplankton Sampling}

Upon conclusion of the experiment, zooplankton were collected using a 2 L Van Dorn type horizontal water sampler. Two water samples, one close to the surface and the other close to the bottom, were collected from each mesocosm and filtered through a $65 \mu \mathrm{m}$ mesh net funnel to recover zooplankton. The recovered material was fixed in 10\% sugar-formalin [36] and a drop of Rose-Bengal stain (stains animal proteins in red) was added to each vial before laboratory analysis to enhance the visibility.

In the laboratory, samples were filtered through a $65 \mu \mathrm{m}$ mesh net funnel again and the materials were suspended in $50 \mathrm{~mL}$ of water. Suspended zooplankton were sub-sampled $(5.0 \mathrm{~mL})$ five times and counted using a counting wheel under a stereo-microscope. Zooplankton were identified to major taxonomic levels using keys provided Pennak [37]. 


\subsection{Statistical Analysis}

\subsubsection{Univariate Analysis}

We restricted our analysis only to the zooplankton taxa which had a cumulative sum of more than 30 individuals (i.e., rotifers, cladocerans, calanoid copepods, cyclopoid copepods, Hydracarina water mites and crustacean nauplii) due to extreme rarity of other taxa (i.e., ostracods, chironomid larvae). All statistical analyses were conducted using $\mathrm{R}$ statistical software program [38]. For zooplankton densities, data were tested for normality with a Shapiro-Wilk normality test (shapiro.test function). Because data were not normally distributed, a Kruskal-Wallis rank sum test (kruskal.test function) was used to test for treatment effects. Separate tests were run for each zooplankton group using population size as the response variable and treatment as the explanatory variable. Post-hoc analyses were conducted by performing a Tukey HSD test (TukeyHSD function) on ranked data [39] with sequential Bonferroni correction [40].

\subsubsection{Multivariate Analysis}

Nonmetric multidimensional scaling (NMDS) was performed to reduce the taxa density matrix of six to two dimensions using metaMDS function in R [38] package "vegan" [41]. The function metaMDS produces an ordination plot by running monoMDS with several random starts until it generates a global optimum after finding two similar ordination configurations with minimum stress [42]. This avoids the risk of finding a local optimum instead of a global optimum as the best solution when using monoMDS alone [42]. This function relativized the data by dividing the maximum value of taxa to improve the quality of the ordination. Because density among taxa varied by four orders of magnitude, relativizing our data set was critical to equalize the impact of individual taxa on the ordination. The ordination was based on a Bray-Curtis distance measure. Taxa relationships to modeled axes were indicated as directional vectors on the ordination plot based on the Pearson Correlation Coefficient for each taxon against the NMDS axes. We considered stress less than 0.20 as an adequate solution [43].

\section{Results and Discussion}

\subsection{Univariate Analysis}

Four of the six zooplankton taxa examined were negatively impacted by the presence of fish; crustacean nauplii, cladocera, calanoid and cyclopoid copepods (Figure 1). In general, the presence of invasive mosquitofish had a higher impact on zooplankton with an average reduction of zooplankton density by $78.8 \%$. The average reduction of zooplankton density due to the presence of endangered Mohave tui chub was $65.1 \%$.

Crustacean nauplii densities were significantly reduced by both mosquitofish $(10.3 \pm$ S.E. 2.03/L) and Mohave tui chub (16.0 \pm S.E. 2.18/L) compared to the fishless control $(35.8 \pm$ S.E. 1.96/L); densities were reduced by $71.2 \%$ and $55.3 \%$, respectively. However, there was no significant difference of nauplii densities between mosquitofish and tui chub treatments (Figure 1a). Cladocerans were virtually eliminated from mosquitofish treatment $(0.2 \pm$ S.E. $0.1 / \mathrm{L})$, compared to both tui chub treatment $(103.7 \pm$ S.E. $11.9 /$ L) and the fishless control (269.6 \pm S.E. 13.1/L; Figure 1b); densities were reduced 
by $99.9 \%$ and $61.6 \%$, respectively. Calanoid copepod densities were reduced by both mosquitofish $(6.65 \pm$ S.E. $0.67 / \mathrm{L})$ and Mohave tui chub $(7.15 \pm$ S.E. $0.61 / \mathrm{L})$ compared to the fishless control (23.3 \pm S.E. 5.0/L; Figure 1c); densities were reduced by $71.4 \%$ and $69.3 \%$ respectively. Similarly, cyclopoid copepod densities were reduced by both mosquitofish (22.05 \pm S.E. 4.23/L) and Mohave tui chub (21.4 \pm S.E. 3.51/L) compared to the fishless control (82.3 \pm S.E. 24.2/L; Figure 1d); densities were reduced by $72.6 \%$ and $74.0 \%$ respectively. However, there were no significant differences for both calanoid and cyclopoid densities between the two fish treatments (Figure 1c,d). Densities of Hydracarina water mites (Figure 1e) and rotifers (Figure 1f) did not significantly differ among treatments.
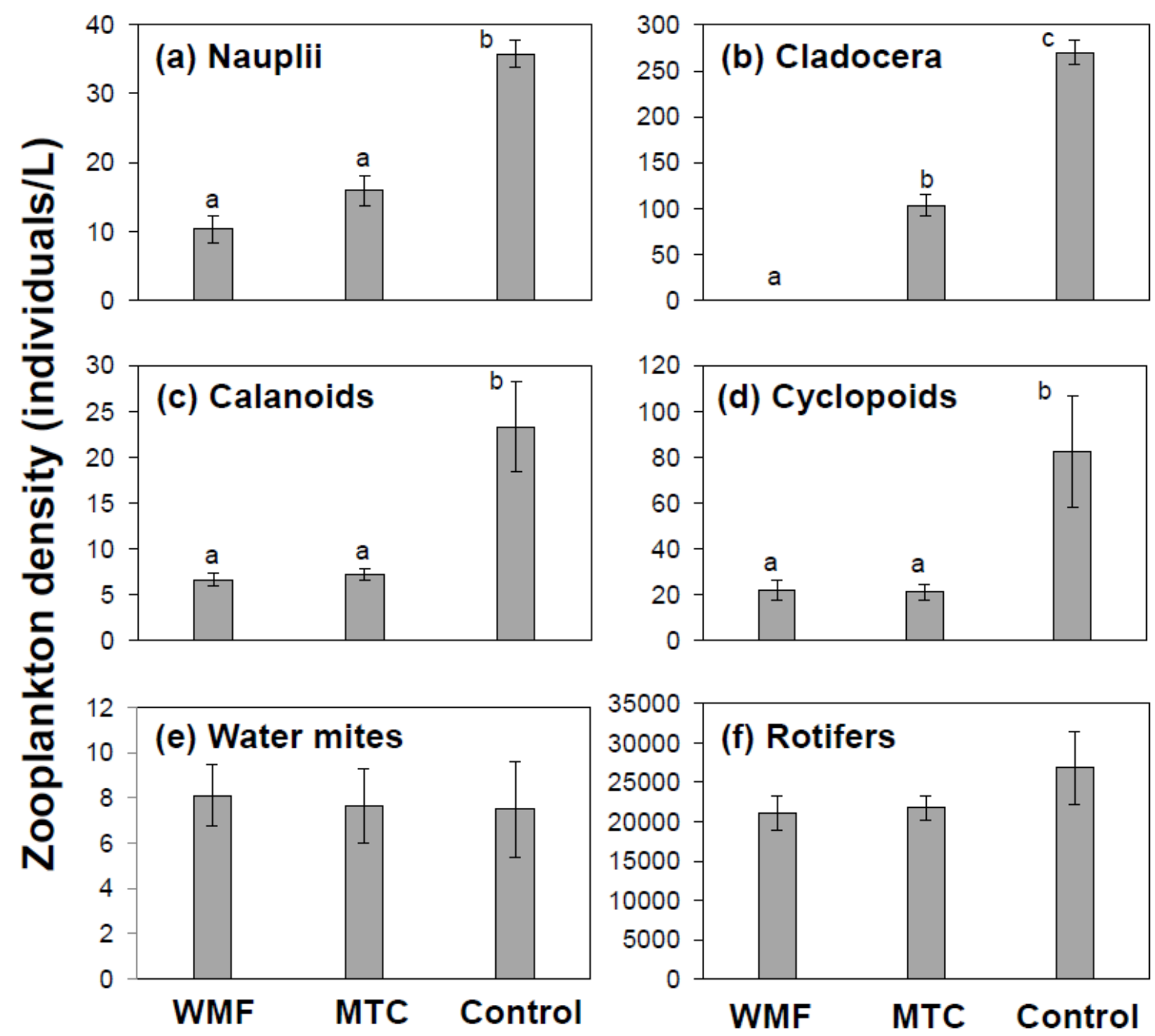

Figure 1. Differences in mean density of major zooplankton taxa among treatments. Significant differences of mean densities were observed for (a) crustacean nauplii $\left(X^{2}{ }_{3}=12.67 ; p=0.002\right)$; (b) cladocera $\left(X^{2}{ }_{3}=21.47 ; p<0.001\right)$; (c) calanoid copepods $\left(X^{2}{ }_{3}=11.76 ; p=0.003\right)$; and (d) cyclopoid copepods $\left(X^{2}{ }_{3}=9.80 ; p=0.007\right)$. No significant treatment differences were observed for (e) water mites and (f) rotifers. Treatment codes: $\mathrm{WMF}=$ allopatric mosquitofish, MTC = allopatric tui chubs, and Control =fishless control. Error bars are one standard error. Similar upper case letters on top of bars indicate nonsignificant pair-wise comparisons after Bonferroni correction. 


\subsection{Multivariate Analysis}

NMDS achieved an adequate two-dimensional solution for zooplankton community assemblage (Figure 2; stress $=0.0901$ ). It generated three distinct clusters which corresponded with the three treatments (Figure 2). The direction and the length of the vector showed a strong negative correlation of cladocerans with mosquitofish. Additionally Hydracarina water mites and rotifers had a positive association with mosquitofish and may indicate lack of mosquitofish impact on them. The relative positioning of the directional vectors may indicate negative associations for copepods and crustacean nauplii both with tui chub and mosquitofish. Furthermore, mosquitofish cluster is located further apart in the ordination space from fishless control cluster compared to Mohave tui chub cluster. This may suggest considerable differences of impacts of tui chubs and mosquitofish on zooplankton communities. This difference is most likely driven by the strong difference between the effects of tui chub and mosquitofish on cladocerans (also see Figure 1b).

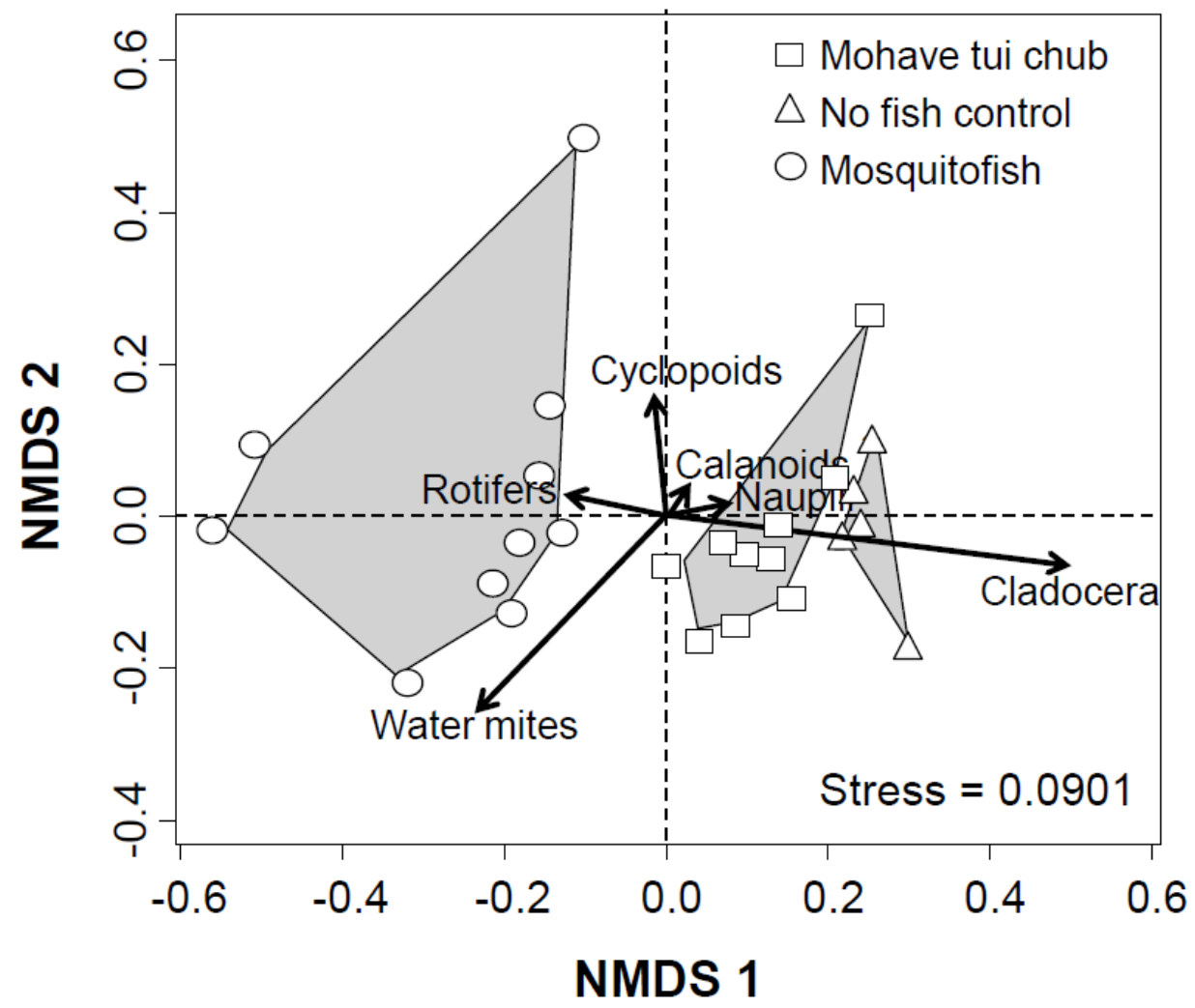

Figure 2. Nonmetric multidimensional scaling (NMDS) ordination plot of experimental units (= mesocosms) for all six-taxa of zooplankton (stress $=0.0901)$. Fish impacts are shown by having separate clusters for treatments with and without fish. Different symbols show three treatments; squares $=$ mosquitofish, circles $=$ Mohave tui chub, and triangles $=$ fishless controls. Symbols represent individual mesocosms and the relative distance between two symbols represent the similarity (or dissimilarity) of zooplankton composition in the relevant mesocosms. Angles and lengths of the vectors represent the direction and the strength of responses of invertebrate taxa to ordination scores, respectively. 


\subsection{Discussion}

Our study shows that both invasive fish and protected fish can impact spring zooplankton communities. Tui chub and mosquitofish both reduced the population density of four out of six invertebrate taxa (crustacean nauplii, cladocera, calanoid copepods, and cyclopoid copepods) compared to the fishless control. Both fish species had similar negative impacts on the densities of crustacean nauplii, calanoid copepods, and cyclopoid copepods, but no significant differences between the fish species treatments. However, invasive mosquitofish had a higher impact on zooplankton density ( $\sim 79 \%$ reduction) compared to the impact of endangered Mohave tui chub on zooplankton density ( $\sim 65 \%$ reduction). While tui chub caused a $60 \%$ reduction in cladoceran densities, mosquitofish virtually eliminated cladocerans with complete extirpation of cladocerans for 8 of 10 mosquitofish mesocosms. By contrast, Hydracarina water mites and rotifers were not affected by the presence of fish.

Our results mimic the findings of earlier workers showing negative effects of mosquitofish presence on invertebrates (both zooplankton and macroinvertebrates [26,27,44-46]), often including the near-complete elimination of cladocerans $[26,27,44,45]$. Our results are also consistent with previous studies that have shown that rotifers escaping fish predation as a result of comparatively very small body size [46] (also see [27]). Additionally, controlled experiments have shown that Hydracarina water mites with red body pigmentation were rejected by fish predators presumably due to distastefulness [47].

The over-riding pattern from this experiment was that both invasive and protected fish species are likely to impact invertebrate communities of desert springs. To our knowledge, this is the first study to experimentally evaluate the impacts of mosquitofish on invertebrate communities of desert springs. More importantly, our study is the first to experimentally evaluate how a commonly used conservation measure for protected fishes can have un-anticipated effects on invertebrate communities. Thus, the benefits of such conservation translocations should be measured against the potential impacts on overall aquatic biodiversity. This is especially important because of the high degree of endemic invertebrate species that occupy desert springs [3-12].

When establishing new populations of protected species, managers typically translocate them within species' historic range to minimize undesirable effects to other native species $[18,19]$. However, in the case of fish translocations, the historic range is typically a watershed, and specifically in an arid landscape, this may include places where the species have never occurred before such as fishless desert springs. Additionally our findings also have relevance for resource managers considering "assisted colonization" as a conservation tool. Proponents of assisted colonization recommend establishing new populations of species at the risk of extinction as a direct result of rapid climate change [48-50]. These introductions typically include areas with suitable climate conditions beyond the historic range of the species of concern $[48,49]$. Therefore, it is critical to thoroughly evaluate the native species composition and potential ecological interactions between native and protected species before such introductions.

Our study specifically shows the potential impacts of two fish species, one native and one invasive, on aquatic invertebrate communities. Although limited, studies of other fishes have shown similar negative impacts on aquatic invertebrates. High densities of native fathead minnows (Pimephales promelas) caused a reduction of abundance, biomass, and taxon richness of aquatic invertebrates in prairie wetlands [51,52]. An enclosure experiment showed reduced densities of benthic predatory chironomids due to bluegill predation [53]. In addition to invasive mosquitofish effects [26-30], the 
presence of non-native tilapia (Tilapia sp.) was associated with reduced species richness and density of invertebrates in a spring-fed habitat [9].

We acknowledge some limitations to our experimental design. For instance, we used tanks with two sizes for fishless control treatment; however, we found that zooplankton densities did not differ between two tank sizes. Further, the invertebrate communities established in the mesocosms were constrained in two ways. First, the spring source for invertebrates (i.e., Lake Tuendae) was not a historically fishless desert spring. Second, filtering of water to exclude fish larvae during the establishment of mesocosms may have limited the introduction of larger macroinvertebrates (e.g. odonate nymphs, amphipods) to mesocosms. However, the Lake Tuendae invertebrate community is dominated by the same zooplankton taxa considered for this analysis [54]. The macroinvertebrate community in Lake Tuendae numerically represents only about $2 \%$ of total invertebrates [34]. Also, our work shows that even with this limitation, that negative effects of mosquitofish and protected Mohave tui chub were qualitatively similar.

\section{Conclusions}

It is important to acknowledge the likelihood that federal and state conservation agencies may well continue to use historically fishless water bodies as prime locations for the introduction of protected fish species. Given the very limited number of suitable refuge sites in the desert, fishless desert springs have been vulnerable targets for conservation translocations [18-20,31]. Therefore a precautionary approach would be to conduct invertebrate surveys of fishless desert springs prior to conducting fish introductions [25]. This single action may alert managers to potential conflicts in conserving aquatic biodiversity and simultaneously enhance our understanding of the inherent biodiversity of fishless desert springs.

\section{Acknowledgments}

We thank Brandon Kowalski, Nathan Stroh and Eric Hanson for assistance with field work; Debra Hughson (National Park Service), Steve Parmenter (California Department of Fish and Game), Rob Fulton and Jason Wallace (Desert Studies Center) for logistical and field support; Don Sada and Shawn Goodchild for unpublished information; Shawn Goodchild, Don Sada, Bodini Herath, Thilina Surasinghe and three anonymous reviewers for reviewing an early draft of the manuscript; This work has been conducted under NPS permit MOJA-2006-SCI-0014, USFWS permit TE126141-0.22 and NDSU IACUC \#A0902 to Craig Stockwell. This work was supported by a NPS grant administered through Mojave National Preserve (Debra Hughson) to Craig Stockwell, a grant from the Western National Parks Association to Craig Stockwell and Sujan Henkanaththegedara, and a grant from California Desert Research Fund to Sujan Henkanaththegedara.

\section{Author Contributions}

Sujan Henkanaththegedara and Craig Stockwell conceived the study and Sujan Henkanaththegedara conducted the study and analysis; Justin Fisher assisted with field experiments and invertebrate sampling; Daniel McEwen assisted with multivariate analysis of the data; Sujan Henkanaththegedara and Craig Stockwell wrote the paper with inputs from Justin Fisher and Daniel McEwen. 


\section{Conflicts of Interest}

The authors declare no conflict of interest.

\section{References}

1. Williams, J.E.; Bowman, D.B.; Brooks, J.E.; Echelle, A.A.; Edwards, R.J.; Hendrickson, A.; Landye, J.J. Endangered Aquatic Ecosystems in North American Deserts with a List of Vanishing Fishes of the Region. J. Ariz.-Nev. Acad. Sci. 1985, 20, 1-62.

2. Stevens, L.E.; Meretsky, V.J. Springs ecosystem ecology and conservation. In Aridland Springs of North America: Ecology and Conservation; Stevens, L.E., Meretsky, V.J., Eds.; Arizona-Sonora Desert Museum Studies in Natural History, The University of Arizona Press: Tucson, AZ, USA, 2008; pp. 3-10.

3. Shepard, W.D. Desert springs-both rare and endangered. Aquat. Conserv. Mar. Freshw. Ecosyst. 1993, 3, 351-359.

4. Hershler, R.; Sada, D.W. Springsnails (Gastropoda: Hydrobiidae) of Ash Meadows, Amargosa Basin, California-Nevada. Proc. Biol. Soc. Wash. 1987, 100, 776-843.

5. Hershler, R.; Sada, D.W. Biogeography of Great Basin aquatic snails of the genus Pyrgulopsis. In Great Basin Aquatic Systems History; Heshler, R., Madsen, D., Currey, D.R., Eds.; Smithsonian Contributions to the Earth Science: Washington, DC, USA, 2002; pp. 283-298.

6. Shepard, W.D. Microcylloepus formicoideus (Coleoptera: Elmidae), A new riffle beetle from Death Valley National Monument, California. Entomol. News 1990, 101, 147-153.

7. Polhemus, D.A.; Polhemus, J.T. Basin and ranges: The biogeography of aquatic true bugs (Insecta: Heteroptera). In Great Basin Aquatic Systems History; Heshler, R., Madsen, D., Currey, D.R., Eds.; Smithsonian Contributions to the Earth Science: Washington, DC, USA, 2002; pp. 235-254.

8. Hershler, R.; Liu, H.; Landye, J.J. New species and records of spring snails (Caenogastropoda: Cochliopidae: Tryonia) from the Chihuahuan Desert (Mexico and United States), an imperiled biodiversity hotspot. Zootaxa 2011, 3001, 1-32.

9. Bogan, M.T.; Noriega-Felix, N.; Vidal-Aguilar, S.L.; Gutiérrez-Ruacho, O.G.; Findley, L.T.; Lytle, D.A.; Alvarado-Castro, J.A.; Varela-Romero, A. Biogeography and conservation of aquatic fauna in spring-fed tropical canyons of the southern Sonoran Desert, Mexico. Biodivers. Conserv. 2014, 23, 2705-2748.

10. Walsh, E.J.; Schröder, T.; Wallace, R.L.; Ríos-Arana, J.V.; Rico-Martínez, R. Rotifers from selected inland saline waters in the Chihuahuan Desert of Mexico. Saline Syst. 2008, doi:10.1186/1746-1448-4-7.

11. Hale, J.R.; Mims, M.C.; Bogan, M.T.; Olden, J.D. Links between two interacting factors, novel habitats and non-native predators, and aquatic invertebrate communities in a dryland environment. Hydrobiologia 2014, doi:10.1007/s10750-014-2024-0.

12. Suárez-Morales, E.; Gutiérrez-Aguirre, M.A.; Walsh, E.J. Freshwater Copepoda (Crustacea) from the Chihuahuan Desert with Comments on Biogeography. Southwest. Nat. 2010, 55, 525-531. 
13. Unmack, P.J.; Minckley, W.L. The demise of desert springs. In Aridland Springs of North America: Ecology and Conservation; Stevens, L.E., Meretsky, V.J., Eds.; Arizona-Sonora Desert Museum Studies in Natural History, The University of Arizona Press: Tucson, AZ, USA, 2008; pp. 11-34.

14. Pister, E. Desert fishes and their habitats. Trans. Am. Fish. Soc. 1974, 3, 531-540.

15. Meffe, G.K. Predation and species replacement in American southwestern fishes: A case study. Southwest. Nat. 1985, 30, 173-187.

16. Deacon, J.E.; Williams, C.D. Ash Meadows and the legacy of the Devils Hole pupfish. In Battle Against Extinction: Native Fish Management in the American West; Minckley, W.L., Deacon, J.E., Eds.; The University of Arizona Press: Tucson, AZ, USA, 1991; pp. 69-87.

17. Soltz, D.L.; Naiman, R.J. The Natural History of Native Fishes in the Death Valley System; Science Series 30; Natural History Museum of Los Angeles County: Los Angeles, CA, USA, 1978.

18. Hendrickson, D.A.; Brooks, J.E. Transplanting short-lived fishes in North American deserts: Review, assessment, and recommendations. In Battle Against Extinction: Native Fish Management in the American West; Minckley, W.L., Deacon, J.E., Eds.; The University of Arizona Press: Tucson, AZ, USA, 1991; pp. 283-298.

19. Minckley, W.L. Translocation as a tool for conserving imperiled fishes: Experiences in western United States. Biol. Conserv. 1995, 72, 297-309.

20. Hoover, F.; Amant, J.A., St. Results of Mohave tui chub (Gila bicolor mohavensis) relocations in California and Nevada. Calif. Fish Game 1983, 69, 54-56.

21. U.S. Fish \& Wildlife Service. Recovery Plan Pahrump Killifish; U.S. Fish \& Wildlife Service: Portland, OR, USA, 1980.

22. Johnson, J.E.; Hubbs, C. Status and Conservation of Poeciliid Fishes. In Ecology and Evolution of Livebearing Fishes (Poeciliidae); Meffe, G.K., Snelson, F.F., Jr., Eds.; Prentice Hall Advanced Reference Series, Prentice Hall Inc.: Upper Saddle River, NJ, USA, 1989; pp. 301-317.

23. Roemer, G.W.; Wayne, R.K. Conservation in conflict: The tale of two endangered species. Conserv. Biol. 2003, 17, 1251-1260.

24. Gumm, J.M.; Sneckser, J.L.; Itzkowitz, M. Conservation and conflict between endangered desert fishes. Biol. Lett. 2008, 4, 655-658.

25. Gumm, J.M.; Sneckser, J.L.; Leesa, J.M.; Little, K.P.; Leiser, J.K.; Imhoff, V.E.; Westrick, B.; Itzkowitz, M. Management of interactions between endangered species using habitat restoration. Biol. Conserv. 2011, 144, 2171-2176.

26. Hurlbert, S.H.; Zedler, J.; Fairbanks, D. Ecosystem alteration by mosquitofish (Gambusia affinis) predation. Science 1972, 175, 639-641.

27. Angeler, D.G.; Álvarez-Cobelas, M.; Sánchez-Carrillo, S.; Rodrigo, M.A. Assessment of exotic fish impacts on water quality and zooplankton in a degraded semi-arid floodplain wetland. Aquat. Sci.-Res. Bound. 2002, 64, 76-86.

28. Stockwell, C.A.; Henkanaththegedara, S.M. Evolutionary Conservation Biology of Poeciliids. In Ecology and Evolution of Poeciliid Fishes; Evan, J., Pilastro, A., Schlupp, I., Eds.; University of Chicago Press: Chicago, IL, USA, 2011; pp. 128-141.

29. Leyse, K.E.; Lawler, S.P.; Strange, T. Effects of alien fish, Gambusia affinis, on an endemic California fairy shrimp, Linderiella occidentalis: Implications for conservation of diversity in fishless waters. Biol. Conserv. 2004, 118, 57-65. 
30. Moyle, P.B. Fish introductions in California: History and impact on native fishes. Biol. Conserv. 1976, 9, 101-118.

31. Miller, R.R. Records of some native freshwater fishes transplanted in to various waters of California, Baja California and Nevada. Calif. Fish Game 1968, 54, 170-179.

32. U.S. Fish \& Wildlife Service. Recovery Plan for the Mohave Tui Chub; Gila bicolor mohavensis, United States Fish and Wildlife Service: Portland, OR, USA, 1984; pp. 1-56.

33. Henkanaththegedara, S.M.; Stockwell, C.A. Melanism in Endangered Mohave Tui Chub Siphateles Bicolor Mohavensis Snyder 1918 (Cypriniformes: Cyprinidae). West. North Am. Nat. 2011, 71, 127-130.

34. Henkanaththegedara, S. Longwood University, Farmville, VA, USA. Unpublished work, 2011.

35. Henkanaththegedara, S.M.; Stockwell, C.A. Intraguild predation may facilitate coexistence of native and non-native fish. J. Appl. Ecol. 2014, 51, 1057-1065.

36. Lind, O. Handbook of Common Methods in Limnology, 2nd ed.; Kendall/Hunt Publishing Company: Dubuque, IA, USA, 1985; p. 33.

37. Pennak, R.W. Fresh-Water Invertebrates of the United States: Protozoa to Mollusca, 3rd ed.; Wiley-Interscience: New York, NY, USA, 1989; pp. 1-656.

38. R Development Core Team. R: A Language and Environment for Statistical Computing. R Foundation for Statistical Computing, Vienna, Austria, 2010. Available online: http://www.Rproject.org (accessed on 12 August 2012).

39. Zar, J.H. Biostatistical Analysis, 5th ed.; Prentice Hall Inc.: Upper Saddle River, NJ, USA, 2010;

40. Rice, W.R. Analyzing tables of statistical tests. Evolution 1989, 43, 223-225.

41. Oksanen, J.; Blanchet, F.G.; Kindt, R.; Legendre, P.; Minchin, P.R.; O’Hara, R.B.; Simpson, G.L.; Solymos, P.; Henry, M.; Stevens, H.; et al. Vegan: Community Ecology Package. R package version 2.0-4, 2011. Available online: http://CRAN.R-project.org/package=vegan2011 (accessed on 12 August 2012).

42. Oksanen, J. Multivariate analysis of ecological communities in R: Vegan tutorial, 2011. Available online: http://cc.oulu.fi/ jarioksa/opetus/metodi/vegantutor.pdf (accessed on 12 August 2012).

43. McCune, B.; Grace, J.B. Analysis of Ecological Communities; MjM Software Design: Gleneden Beach, OR, USA, 2002; pp. 125-142.

44. Hurlbert, S.H.; Mulla, M.S. Impacts of mosquitofish (Gambusia affinis) predation on plankton communities. Hydrobiologia 1981, 83, 125-151.

45. Preston, D.L.; Henderson, J.S.; Johnson, P.T.J. Community ecology of invasions: Direct and indirect effects of multiple invasive species on aquatic communities. Ecology 2012, 93, $1254-1261$.

46. Brooks, J.L.; Dodson, S.I. Body Size, and Composition of Plankton. Science 1965, 150, $28-35$.

47. Kerfoot, W.C. A question of taste: Crypsis and warning coloration in fresh water zooplankton communities. Ecology 1982, 63, 538-554.

48. Hunter, M.L. Climate Change and Moving Species: Furthering the Debate on Assisted Colonization. Conserv. Biol. 2007, 21, 1356-1358.

49. McLachlan, J.H.; Hellmann, J.J.; Schwartz, M.W. A Framework for Debate of Assisted Migration in an Era of Climate Change. Conserv. Biol. 2007, 21, 297-302. 
50. Hoegh-Guldberg, O.; Hughes, L.; McIntyre, S.; Lindenmayer, D.B.; Parmesan, C.; Possingham, H.P.; Thomas, C.D. Assisted Colonization and Rapid Climate Change. Science 2008, 321, 345-346.

51. Hanson, M.A.; Riggs, M.R. Potential effects of fish predation on Wetland invertebrates: A comparison of wetlands with and without fathead minnows. Wetlands 1995, 15, 167-175.

52. Zimmer, K.D.; Hanson, M.A.; Butler, M.G. Effects of Fathead Minnow Colonization and Removal on a Prairie Wetland Ecosystem. Ecosystems 2001, 4, 346-357.

53. Gilinsky, E. The Role of Fish Predation and Spatial Heterogeneity in Determining Benthic Community Structure. Ecology 1984, 65, 455-468.

54. Henkanaththegedara, S.M. Ecological Complexity of Non-Native Species Impacts in Desert Aquatic Systems. Ph.D. Thesis, North Dakota State University, Fargo, ND, USA, 2011.

(C) 2015 by the authors; licensee MDPI, Basel, Switzerland. This article is an open access article distributed under the terms and conditions of the Creative Commons Attribution license (http://creativecommons.org/licenses/by/4.0/). 